\title{
Emotional distress and its care in empowered indigenous women exposed to domestic violence and the demands of child rearing
}

\author{
Leticia Vega, 'Rafael Gutiérrez,' Patricia Fuentes de lturbe,' Eva Ma. Rodríguez'
}

Dirección de Investigaciones Epidemiológicas y Psicosociales, Instituto Nacional de Psiquiatría Ramón de la Fuente Muñiz, Ciudad de México, México.

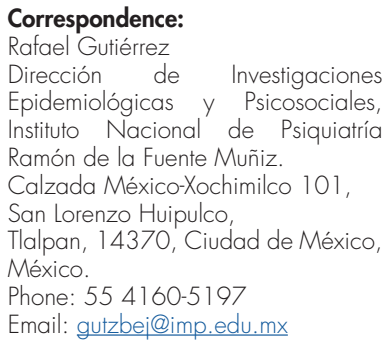

Received: 26 September 2019

Accepted: 6 May 2020

Citation:

Vega, L., Gutiérrez, R., Fuentes de lturbe, P., \& Rodríguez, E. M. (2021). Emotional distress and its care in empowered indigenous women exposed to domestic violence and the demands of child rearing. Salud Mental, 44(2), 65-73.

DOI: $10.17711 / S M .0185-3325.2021 .010$

\begin{abstract}
Introduction. Indigenous girls and women in Mexico suffer emotional distress due to marital violence and adherence to gender roles. They are unlikely to denounce violence or treat their health in a timely manner. Women can cope with their distress by participating in empowerment processes. Objective. Describe in indigenous empowered women the emotional distress caused by domestic violence in their childhood and the current demands of raising their children and the actions they take to cope with them. Method. Qualitative and phenomenological qualitative research, in-depth interviews, and participant observation were conducted with nine migrant indigenous women to explore experiences during their upbringing, emotional reactions, and current mental health problems. Results. The software Atlas. ti $\vee 7$ was used to undertake a theoretical categorization of the data. Findings included exposure to violence, the influence of a good mother, and past and present emotional distress overcome through empowerment and professional care. Discussion and conclusion. Participating in urban empowerment activities enables participants to reflect on the violence experienced and the attendant distress, identify them as gender violence, and use them in their favor. They are strategic when coping with current distress due to the conflictive upbringing of their children, using psychological services and the urban upbringing prescriptions of children's rights, and incorporating indigenous parenting practices, which encourage community commitment, responsibility, and early self-sufficiency in children. Empowerment is suggested as an effective means of improving the health of indigenous women in Mexico.
\end{abstract}

Keywords: Indigenous women, gender violence, emotional distress, empowerment, upbringing, professional care.

\section{RESUMEN}

Introducción. En México, niñas y mujeres indígenas padecen malestares emocionales por la violencia conyugal y el cumplimiento de roles de género. No es común que se denuncie la violencia o se atienda oportunamente su salud. Las mujeres pueden emprender la atención de sus malestares al participar en procesos de empoderamiento. Objetivo. Describir en mujeres indígenas empoderadas los malestares emocionales causados por la violencia doméstica en su niñez; por las exigencias actuales en la crianza de sus hijos/as y las acciones que realizan para atenderlos. Método. Mediante una investigación cualitativa situada y fenomenológica, se realizaron entrevistas en profundidad y observación participante con nueve mujeres indígenas migrantes. Con estas herramientas se exploraron experiencias durante su crianza; reacciones emocionales y problemas actuales de salud mental. Resultados. Mediante el software Atlas. ti $\vee 7$, se realizó una categorización teórica de los datos. Así se encontraron: exposición a la violencia; la influencia de la buena madre; malestares emocionales antiguos y actuales sobrellevados con el empoderamiento y la atención profesional. Discusión y conclusión. Participar en actividades urbanas de empoderamiento lleva a las participantes a reflexionar sobre la violencia vivida y sus malestares asociados; resituarlos como violencia de género, y usarlos en su favor. Se muestran estratégicas al enfrentar malestares actuales por la conflictiva crianza de su hijos/ as, usando servicios psicológicos y las prescripciones de crianza urbana del derecho infantil, e integrando prácticas de crianza indígenas, que estimulan el compromiso comunitario, responsabilidad y autosuficiencia temprana en los hijos/as. Se sugiere aprovechar la eficacia del empoderamiento para mejorar la salud de las mujeres indígenas del país.

Palabras clave: Mujeres indígenas, violencia de género, malestares emocionales, empoderamiento, crianza, atención profesional. 


\section{INTRODUCTION}

Indigenous women in Mexico are exposed to multiple forms of violence in their families, towns, and communities (National Institute of Public Health, 2008; INEGI, 2012; Valdez-Santiago, Híjar, Rojas Martínez, Ávila Burgos, \& Arenas Monreal, 2013). Anthropological and psychosocial research describes the interpretations indigenous women give to their mental health problems derived from lived conjugal violence and the demands of fulfilling gender roles, using qualitative research techniques and theoretical constructs, such as "discomfort." This concept includes subjective sensations and biological signs that occur in oppressive social situations, interpreted as sadness, a feeling of emptiness, muscular pains and headaches, insomnia, fatigue, worry, nerves, and irritability (Berenzon Gorn et al., 2014). For example, Otomi women's interpretations of the symptoms derived from spousal violence include death wishes, suicide attempts, loneliness, mixed feelings, rage, anger, despair, wanting to cry all the time, being traumatized, fear, nerves, feeling nervous, listlessness, loss of sexual desire, worry, guilt, obsessive ideas, difficulty in getting out of bed, and sadness (Tiburcio Sainz, 2009). In another qualitative study, women from the various ethnic groups in Mexico regarded experiencing sadness, isolation, suicidal feelings, and alcohol and drug use due to conjugal violence and the demands of gender roles (Bonfil Sánchez, De Marinis, Xotlanihua, \& Martínez Navarro, 2017). Several types of discomfort identified by indigenous women who have been abused have also been reported by women in oppressive situations in other parts of the world (Devries et al., 2011).

Many indigenous women suffer this discomfort in silence, do not report violence to municipal and police authorities, and act according to the patriarchal structure of their villages, some cautiously (Suárez Elizalde, 2009), and others with submission, tolerance, and resignation (Suárez Elizalde, 2009; Natera Rey, Callejas Pérez, Barker, Little, \& Medina Aguilar, 2012). Nor do they seek care at health services (Natera Rey et al., 2012) while those who do, fail to complete treatment (Suárez Elizalde, 2009) due to the demands of fulfilling gender roles, but also to the barriers to health services, such as remote location, culturally inappropriate programs, discriminatory attitudes, and rejection from an overworked medical service that has received limited training to detect emotional distress (Berenzon Gorn et al., 2014). It seems that, under these conditions, indigenous women who have been abused are powerless victims, condemned to suffer until death comes. It has been observed, however, that submissive victims do not give up in the face of adversity. For example, Scheper-Hughes (1992) describes the creative ways suffering Brazilian women use to stay alive in a culture of silence and terror, while Das (2008) highlights the appropriations and reframing of the traumatic experiences of raped women to carry on with their lives amid the devastation of India's ethnic wars. Moreover, in Mexico, researchers have observed the participation of suffering indigenous women who seek to improve their living conditions by taking part in collectives and social organizations with widely different approaches (religious, gender, biomedical, community development, etc.), where they speak and reflect with other women about the everyday problems they suffer. They receive training and assume leadership roles to promote economic, health, and education projects for indigenous peoples, and to participate in collective actions to modify the conditions oppressing them. For example, one of the first actions of Nahua women organized in a Catholic collective in the 1970s was to shut down and relocate canteens and brothels after using a biblical perspective to reflect on the alcoholism of their partners, bigamy, divorce, deaths from alcohol consumption, and the excessive number of canteens and brothels in their town (Duarte Bastián, 2008). An organization of Nahua, Amuzgo, Tlapanec, and Mixtec women from the state of Guerrero, previously resigned to the violence of their partners, allowed them to use a gender perspective to reflect on their experiences and to organize to defend themselves legally and seek refuge (Carrillo-De la Cruz, Zapata-Martelo, Ayala-Carrillo, \& Díaz-Cervantes, 2015). Other reports point out that women's participation in groups helps them improve their situation (Klein \& Vázquez-Flores, 2013; Pérez Villar, Vázquez García, \& Zapata Martelo, 2008; Morokvasic, 2007; González Montes, 2009; Orton et al., 2016).

Agency or the capacity of people to change the conditions that affect them has been recognized and promoted in the primary health care field since the 1970s (De Vos et al., 2009). Efforts have therefore been made to promote the involvement of individual and community participation in decision-making to improve the social, economic, and political conditions that impact health. Nowadays, the concept of empowerment is used in the field of health promotion to refer to individual or collective involvement in a process where people and communities are gradually able to express their demands, assume greater control over the decisions and actions that affect their health, and undertake political, social, and cultural actions to address their needs. To this end, health programs with an empowerment approach implemented in various parts of the world (Lindacher, Curbach, Warrelmann, Brandstetter, \& Loss, 2018) usually include the construction of participatory strategies, critical awareness, and problem solving among socially disadvantaged groups.

The aims of this research are to a) describe the interpretations of indigenous women inserted in empowerment processes of the suffering they experienced during childhood when they were exposed to violence at the hands of their fathers; b) identify the discomfort of women in empowerment processes, derived from the demands of gender roles, specifically child rearing; and c) record the actions they undertake to assuage this discomfort. These issues have barely been 
explored in the Mexican indigenous population, despite the compelling evidence that parenting is stressful and that witnessing spousal violence can have adverse consequences in the short and long term for children who witness it (Callaghan, Alexander, Sixsmith, \& Fellin, 2018). Obtaining this information would help to identify the needs of indigenous women, recognize their capacity for agency, and legitimize and strengthen the programs designed to empower them.

\section{METHOD}

\section{Design of the study}

To explore the perspective of indigenous women, a qualitative, situated research project (Denzin \& Lincoln, 2012) of a phenomenological nature (Taylor \& Bogdan, 1987) was developed. To this end, rapport was built and observation, and in-depth interviews were carried out with the women in the settings they frequented. These interactions yielded a diversity of meanings about the problems experienced in their homes and their reactions to them. All the conversations were transcribed, and their contents interpreted to understand the meanings the women expressed based on their cultural frame of reference: the context of their past and their current situation. These interpretations were shown to the women and discussed with them until they were satisfied with what had been interpreted.

\section{Subjects/description of the sample}

Nine migrant indigenous women from various ethnic groups (Nahua, Mazahua, Otomi, Mixtec, and Mazatec) participated. They were all residents of Mexico City, spoke an indigenous language and Spanish, were an average of 39 years old, and had had fathers with problematic alcohol use. Three came from the state of Puebla, three from the State of Mexico, and three from the state of Oaxaca. The characteristics and pseudonyms of the participants are given in Table 1. All the women worked in a collective as translator-interpreters for indigenous individuals and groups living in the city, those in conflict with the law and health institutions.

\section{Places}

Participant observation was carried out in various settings frequented by the participating women (workplace, training room, home, school, metro stations, and public squares). The authors engaged in intense communication with them during the rapport stage, when they exchanged everything from thoughts, ideas, and jokes, to silence in certain circumstances.

The main setting for the observation was a classroom, where two of the authors trained the women in community intervention methods to discourage alcohol consumption. The other two authors participated in the group of women who received the training. From there they observed, recorded what was happening, and built rapport with the participating women, interacting with them in a non-offensive way, so that they felt comfortable and continued to participate without feeling they were being researched. When the women participated in the workshop, the authors listened to them, showing interest, especially when they talked about their problems or what they did to cope with them.

After the training, the authors invited the women to chat in places where they could interview them in depth, without the presence of other people or distractors. They chose their workplace, the room where people were trained for interviews, or their homes.

Table 1

Sociodemographic data of study participants

\begin{tabular}{|c|c|c|c|c|c|c|c|c|c|}
\hline & Soledad & Remigia & Esperanza & Mercedes & Mariana & Obdulia & Sara & Ramona & Rigoberta \\
\hline Place of birth & Puebla & Puebla & Puebla & $\begin{array}{l}\text { Mexico } \\
\text { State }\end{array}$ & $\begin{array}{l}\text { Mexico } \\
\text { State }\end{array}$ & $\begin{array}{l}\text { Mexico } \\
\text { State }\end{array}$ & Oaxaca & Oaxaca & Oaxaca \\
\hline Age & 37 & 38 & 39 & 49 & 39 & 38 & 39 & 40 & 41 \\
\hline $\begin{array}{l}\text { Educational } \\
\text { Attainment }\end{array}$ & $\begin{array}{l}\text { High } \\
\text { school }\end{array}$ & Degree & Degree & $\begin{array}{l}\text { High } \\
\text { school }\end{array}$ & $\begin{array}{l}\text { High } \\
\text { school }\end{array}$ & $\begin{array}{l}\text { High } \\
\text { school }\end{array}$ & Degree & $\begin{array}{l}\text { High } \\
\text { school }\end{array}$ & High school \\
\hline Indigenous language & Nahuatl & Nahuatl & Otomí & Mazahua & Otomí & Mazahua & Mazatec & Mixtec & Mazatec \\
\hline Marital status & Separated & $\begin{array}{l}\text { Living } \\
\text { together }\end{array}$ & Separated & Separated & $\begin{array}{l}\text { Living } \\
\text { together }\end{array}$ & $\begin{array}{l}\text { Single } \\
\text { mother }\end{array}$ & $\begin{array}{l}\text { Single } \\
\text { mother }\end{array}$ & Married & Separated \\
\hline Parity & 2 & 3 & 2 & 3 & 2 & 2 & 2 & 4 & 3 \\
\hline Occupation & $\begin{array}{l}\text { Translator/ } \\
\text { Interpreter }\end{array}$ & $\begin{array}{l}\text { Translator/ } \\
\text { Interpreter }\end{array}$ & $\begin{array}{l}\text { Translator/ } \\
\text { Interpreter }\end{array}$ & $\begin{array}{l}\text { Translator/ } \\
\text { Interpreter }\end{array}$ & $\begin{array}{l}\text { Translator/ } \\
\text { Interpreter }\end{array}$ & $\begin{array}{l}\text { Translator/ } \\
\text { Interpreter }\end{array}$ & $\begin{array}{l}\text { Translator/ } \\
\text { Interpreter }\end{array}$ & $\begin{array}{l}\text { Translator/ } \\
\text { Interpreter }\end{array}$ & $\begin{array}{l}\text { Translator/ } \\
\text { Interpreter }\end{array}$ \\
\hline $\begin{array}{l}\text { No. of empowerment } \\
\text { workshops }\end{array}$ & 9 & 7 & 8 & 8 & 9 & 8 & 10 & 9 & 10 \\
\hline $\begin{array}{l}\text { Organizations in which } \\
\text { they have participated }\end{array}$ & 3 & 4 & 6 & 4 & 7 & 5 & 5 & 4 & 5 \\
\hline
\end{tabular}




\section{Measurements}

For the interviews, a script with open-ended questions was used, which asked subjects to describe a) the best and worst experiences during their upbringing and the current upbringing of their children; b) the emotional reactions caused by this; and c) current mental health problems and what they do about them. After each question, descriptive questions were improvised until a detailed picture of the situation presented by the women was obtained. When no more new information appeared, the next question in the script was asked. Two one-hour interview sessions were held. All the interviews were audio recorded, transcribed, accompanied by notes on their context, and reviewed by the participating women. Once accepted, the transcripts were interpreted by the authors, whose interpretation was also discussed with the women interviewed.

The observation guide used was refined throughout the fieldwork. It began with a few places and events to observe so that they could be recorded in the field diary, such as the setting of the explanations given, the rapport established with the informants by the researchers, the women's participation, and the reactions of others in the workshop, when information about situations that cause discomfort or illness, and their care was provided. The guide subsequently incorporated other places and situations to understand the object of study and triangulate the information (such as visits to the women's homes and the children's schools to observe child-rearing situations, visits to their workplaces to see how they organize the projects, cases of violence attended by the women's collective, and participation in street marches), which were obtained from the rapport established, the analysis of field diaries, the interviews conducted, and other research on the subject in question.

\section{Procedures}

The women participants in the study were selected through non-probabilistic convenience and snowball sampling. They were selected because they belonged to the population of interest and were available. To this end, first five women known from a previous study on alcohol consumption in indigenous communities were contacted via email (Vega et al., 2015). They were subsequently personally invited to participate in a training workshop to engage in community intervention to discourage alcohol consumption in the villages and in a research project on mental health problems and their care. All the women contacted agreed to participate. Afterwards, the snowball sampling was carried out, during which the five women invited another four interpreters to a meeting where the authors invited them to participate in the training workshop and research project, in which they agreed to take part.

The workshop was given by a couple of authors, once a week, for three months in a room owned by one of the participants and in a classroom. The workshop included an explanation of the risk factors for alcohol consumption in the communities: stress, normalization, and consumer experiences, as well as practice interviews and focus groups to evaluate them. The speakers encouraged the women to give examples of each of the risk factors explained and to practice interviews and focus groups, in which they spontaneously discussed their own past and present experiences. Everything that was said and done during the presentations was written down and contextualized with the authors' notes in a journal.

\section{Statistical analysis}

The information transcribed was compiled as primary documents in a single hermeneutical unit of Atlas.ti 7 software. All the documents were read several times until a general understanding was achieved, which made it possible to identify relevant expressions, paragraphs, and topics for the research objectives. Using Atlas.ti 7, two researchers worked independently and together to develop the coding tree for primary documents deductively and inductively. They stopped when no further new codes appeared, and no lines were left uncoded.

The categorization grouped the written lines and paragraphs from the primary documents into codes that captured their meaning. These codes were concepts of theories unknown to the subjects and expressions that were significant to them. Each code was then grouped with others into broader categories, which in turn focused on different topics. Afterwards, a re-categorization was carried out, where the codes and themes were contrasted using the constant comparison method of Ground Theory (Strauss \& Corbin, 1990), until the information obtained was reduced to the following topics: paternal violence; the good mother; emotional discomfort; empowerment, parenting, and professional psychological care.

\section{Ethical considerations}

Each of the participants received a letter introducing the authors as researchers, with their name and work address. The letter requested their voluntary consent, guaranteeing their confidentiality and anonymity, to participate in the training workshops, participatory observation, and interviews. The objectives were explained to the women, who were told what the research techniques consisted of, where they would be implemented, and how long they would last. All the subjects were offered referrals to psychological services in Mexico City. All the letters were signed by the women, authorizing their voluntary participation. Only the researchers and women participants were present in the interviews. The transcripts were made by people outside the research and reviewed by the authors to guarantee the anonymity of 
the participants and ensure that they contained no errors. In addition, the transcripts were filed on a computer, and assigned numerical codes not linked to indigenous names or collectives. The lead researcher was the only person with access to the password for this computer.

Ethical approval was obtained from the Research Ethics Committee of the Instituto Nacional de Psiquiatría Ramón de la Fuente Muñiz [INPRFM, National Institute of Psychiatry], on June 4, 2018: CEI / C / 037/2018.

\section{RESULTS}

\section{Characteristics of informants}

Records of the participatory observation undertaken in the workplaces and homes of the participating women contain information that exemplifies the empowerment indicators provided for Mexican women (Hernández Sánchez \& García Falconi, 2008): a) cultural capital: all of them have completed high school, with three holding bachelor's degrees, and have attended several training workshops on ethnicity, citizenship, and gender; b) temerity: they participate in marches and indigenous organizations that fight for urban spaces for commerce, housing, health, and education. They also rotate the leadership of their collective; c) independence: on their own initiative they constituted an independent group of indigenous women interpreters and translators and make important decisions at home or agree on them with their partners; d) equality: they collaborated as translator interpreters for a government agency in courts, prisons, and hospitals, where they seek equal conditions at work and in the treatment of the indigenous population they serve; e) participatory: in all the above activities they are active, persevering, responsible and demonstrate; f) social satisfaction: especially because the population they serve is grateful for their work; and g) security: they are the only ones who make decisions about their working lives.

As a result of their accumulated experience, these women have gradually developed a deep reflection and awareness of their gender- and ethnicity-based oppression and subordination. It was through this awareness that they were able to speak in this study.

\section{Exposure to violence during childhood}

All the participants had experienced episodes of paternal violence. Their fathers drank alcohol at community and family celebrations and to get through their workday. During the 1990s, fathers drank more often on weekends. There were therefore frequent episodes when they became angry and insulted and threatened their wives and children. However, when they were drunk, they insulted and beat the mothers, sometimes leaving them unable to perform household chores. One of them, encouraged by her daughters, reported her husband to the community authorities:

"Even when she complained to the town authorities that she had been beaten, they did not support her, although the laws were in her favor. The authorities told her it was not a problem of violence, nor was it legal, and that she should fix matters at home. They said, "You must fix that problem. You must patch things up with your husband"... you must make it up to him. I'm going to talk to him right now and I'll send him over to you. Now run along and make him some soup so that when he gets home you will welcome him and get back together again" (Remigia).

In the testimonial, the authorities refuse to support and instead minimize the violence towards the victim. They reject her account, interpreting it as a problem of reconciliation, where the husband must be humored, as if nothing had happened.

\section{The good mother}

Several participants mentioned that their mothers had put up with the fathers' violence because it was the custom in the village. Three women described this as follows:

"You have to put up with your husband so that his children have a father, and the family does not fall apart. When a woman marries a man it is for life. You cannot go it alone, you become impure, indecent" (Mariana, Mercedes, and Remigia).

From the point of view of the community, the more a good mother holds her husband and children together, despite the problems, injustices, and mistreatment, the more she is dignified. Moreover, she does not complain or talk to others about the problems caused by the harsh, controlling, authoritarian relationships of patriarchs, who, the more they show they dominate their wives and children, the better their reputation and the more community recognition they receive. Without alternatives, or useful services nearby, women learn to keep quiet and contain their pain and suffering caused by injustice, humiliation, and violence. It is a way to be able to go about their everyday lives without complaining about the oppression they experience, and apparently enables them to block the pain and grief, at least temporarily and move on and survive:

"It's as though it is not good for us to waste time talking and complaining about what has happened. We keep going because there is a lot of poverty in village life. We all have to work from daybreak. Otherwise, we do not eat. In other words, we do not even have time to turn away to think and complain about the problems, the infidelities, the blows. You feel pain, but you go on working, because you've got no choice, even if you remember and think about things and start crying. At the same time, you press on with your 
chores, making tortillas, attending to your husband, sales, crops and then if there is more to do, sometimes it's better, because it keeps you busy and stops you turning things over in your mind" (Soledad).

Some participants expressed resentment against the good mother, because by putting up with a father who drank, she had exposed the children to violence and suffering for longer:

“... In a way we blamed Mom, you know. Because we said [crying] how did you put up with my dad's drinking for so long? Why? I think he was... we would have been better off without him; and often ... as a daughter I always thought that the best thing would be to get divorced, to have them separate because even though my mother was a fighter, she really believed you had to bear a cross for life, and I think that was the case" (Rigoberta).

Unlike the good mother, several of the participants broke off the relationships they had with alcohol-consuming partners. They were men from their hometowns or the city, who did not contribute to the maintenance or care of their children or encourage them to study and participate in women's groups. They wanted to control them, and some even physically mistreated them. That is why they separated from their partners. Those that remained did so because they had managed to limit the control, irresponsibility, and mistreatment on the part of their partners.

\section{Emotional discomfort and the empowerment to be able to deal with it}

Due to the complacency of the community authorities and the good mother, episodes of violence by the father towards the family group were frequent and produced pain and feelings of helplessness that do not disappear in the victims. The wounds are always there:

“We suffered a lot because of my father's drinking, because my father was very aggressive even towards his children. He was so cruel. It would be one in the morning and he would run us out of the house. Why? Because at that time you were a defenseless girl, you couldn't help your mother when they were beating her. Yes, it hurts, I think the wounds don't close, they don't close" (Esperanza).

They were also scared and anxious the father would engage in bouts of violence:

"My father was such an alcoholic. He didn't drink every day, but he did drink every week. That's what we were scared of. It was scary that your dad would drink, that he would come back like an animal. It's painful because they hurt you from the time you are a child. You think you've got over it, but you haven 't" (Ramona).

At other times they spoke of anger, frustration, resentment, and feelings of inadequacy. They highlighted the fact that they became irritable and complained about reacting violently when they were raising their children. They felt guilty and mortified themselves after scolding and mistreating their children.

The women have retained their emotional wounds. However, now they are capable of talking about the emotions they used to bottle up. This occurs because of encounters with other women, especially in empowerment groups:

"I thought I had already left it in the past, that I had got over or that it no longer mattered. It happened a long time ago but listening to the others [in women's groups] and seeing that we had lived through the same things and then then talking about my life then, well, everything that I experienced as a child because of my alcoholic father came back. I saw all the pain I had been holding in" (Obdulia).

At these meetings, they were exposed to the testimonials of women who had been mistreated, to their analysis and debate from a gender and rights perspectives. As a result, they gradually became aware of the familial, community and urban violence in their lives, as a problem linked to gender inequality in patriarchal cultures. These meetings set the tone so that the testimonials of the violence against them, previously silenced in their villages, could be spoken, heard, and understood by other women:

“Talk! That's what I needed! Not as gossip between women, but to talk properly, to say what hurt me, although it hurt to remember, talking about it unburdened me and helped me, and I cried a lot again, but I understood why this happens to women, because it happened to my mother and my grandmother" (Sara).

Above all, they said how important it was to talk about the pain they had undergone:

"When I was able to speak, to express everything inside me, everything that hurt, what I had suffered as a child, at home, I felt relieved. It did me good, at first, I didn't think about the bad things about my father, my family, and my village. It felt like I was betraying them, but I see that bad things happen in every culture, not just in my village. It helped me to speak because holding in so much pain and resentment makes you bitter about life" (Mercedes).

At the empowerment workshops and reflective meetings on gender violence, they often had professionals who encouraged spaces and activities involving emotional empathy and active listening that made it easier for the participants to recount their discomfort and suffering. This allowed them to name their discomforts and begin to build a narrative around them that they sought to communicate to the oppressed, silenced women in their villages. For example, one informant used community radio to broadcast information to make other women aware of their gender subordination.

According to the participants, getting together with other women, talking about their emotional wounds, be- 
coming aware of gender inequalities, and taking actions to change their situation, helps them cope with their situation.

\section{Current emotional distress, parenting, and professional psychological care}

The women also spoke about their current discomfort. They are concerned about the problems they face in the city such as discrimination and gender and ethnic inequalities, the shortage of jobs and the fight for safe housing.

The participants are mothers concerned about raising their children. Several of them do not have any support from the father, even if they live with him. The women want their children to be obedient, responsible, and self-sufficient, involved in solving the problems of the family and the people from the time they are children. However, all the women stated that they did not want to raise their children with violence, as they had been. One of them says:

"... the thing is I did not want my children to go through what I experienced as a child, poverty, hard work, blows or the fact that my mother did not give us hugs. People don't do that there, and it still happens. When I go to see my mother, I am very happy, because I see her, and I give her an affectionate hug. I kiss her and her arms hang down by her sides and I have to tell her, 'Give me a hug, Mom!' And I have to put her arms around my waist so she can hug me" (Esperanza).

Some participants tried to reproduce the loving nurturing they saw in other neighboring urban families, but with unwanted results. A single mother says:

"... well, I did things differently with my children. I am loving, but I went to the other extreme. I gave them and allowed them everything I could without limits. In return, they became demanding, emotional blackmailers, and irresponsible" (Ramona).

This also happened to women with partners who were not supportive:

"At the beginning, when they were younger, I got things wrong with my children. Well, I did not want to mistreat them, and I allowed them to get away with things and they took advantage and behaved like kings. They did not obey or help around the house and only asked for things for their amusement and if I did not give them to them then they threatened to leave school or leave home and I was the bad one. They told on me to their father, and he covered up for them... that happened because I let them always have their way" (Obdulia).

Despite trying to raise their children lovingly, women who bring them up alone point out that it is common to despair, get angry, and act violently towards them and then regret it:

"Eventually, I was left alone with my children. I was in charge and we did not have their father and I no longer knew what to do, how to talk to my son, how to make him understand, because I even hit him and then I felt worse. I regretted it and he was stubborn and did not even respect the teachers" (Sara).

Other women treated their children affectionately and sometimes smacked them when necessary. These women think that smacking their children is not intended to harm them, but to make them understand. In any case, they are also mortified, because the school authorities question the children's upbringing and absences when they engage in community tasks in the city and the villages.

Due to all the above, several women said they were confused about how to raise indigenous children in urban settings:

"I used to say, what is all this about communicating with children? What can you say to the kids and what can't you? They don't understand everything, and they should obey so that they learn to do things. They should be responsible and respectful, obey without questioning, without explanations. That's what they taught me in my village. Good children are good because they do what they are told, but I still struggled because I saw that here in the city, they talk about rights at school. They say that children must be given information, that you must talk to them, affectionately, so that you understand them. Because I noticed that my neighbors in the city talked to their children a lot" (Mariana).

Amid the confusion, several women sought professional psychological help:

"... Those who did help me were the psychologists of an organization that I was able to work with in several sessions. I also received advice and I put my son in the boy scouts. It was very good, they taught him discipline, but it was with the psychologist that I learned many things about the relationship with my children and I saw that I treat them the way they treated me in the village because although they learn to respect, I also saw other things in the village I don't like. Children can understand if you explain things to them. You should talk more to children and not just give them orders" (Rigoberta).

They value international organizations where children learn discipline and psychological services that provide them with the space to speak and the tools to fix, negotiate and make agreements with the family, to strike a balance between the degree of participation and responsibility of its members. They also realize that they are taught to set limits and appropriate non-violent corrections, when children break the rules agreed on. They fully approve of the child raising guidelines that respect the rights of children and in applying them faithfully. In fact, they believe this is the model every mother should follow. However, all this is subverted in everyday events, when they incorporate indigenous child raising practices, assigning them domestic 
chores, and making them responsible for the reproduction of community customs, but also slipping in physical punishment which they justify, provided it is only used in specific circumstances. One of them says:

"We already tried being nice, but the kids go too far, so it is good to hit them with a flip-flop or shake them or rap them on the head with your knuckles" (Soledad).

\section{DISCUSSION AND CONCLUSION}

Indigenous women occupy subordinate positions in gender and ethnic relations that restrict them in the city and their villages. However, they are not completely conditioned to accept the limits imposed on them with submission and resignation.

There are indigenous women who are exposed to violence from parents with problematic alcohol consumption, which causes them emotional distress that persists into adulthood. However, rather than resigning themselves to suffering violence and discomfort in silence, as tradition demands or have them dealt with by health services, the women who participated here appropriated these forms of discomfort during their empowerment process and planned actions in groups to support women in their villages who have been abused. Talking about this discomfort in collectives not only helps women vent their feelings, but also seems to allow them to deliberately hold on to their emotional wounds, to consciously bear them and articulate them in their fight against gender violence in their villages. Similar strategies of holding on to suffering are reported as a means of subverting the patriarchal mandate (Almario García et al., 2008).

In the city, the women participants also play an active role in the processes of appropriation and recreation of parenting discourses and practices promoted at school and in the media, especially when they find it difficult to raise their children because they behave in a rebellious, irresponsible manner. The participants do not want to raise their children by replicating the violence with which they were raised. They try to act affectionately, but in adverse situations they despair and behave violently, while others are permissive. Although they use and value the psychological services provided and attempt to follow their recommendations to achieve loving parenting with limits, in reality they incorporate indigenous parenting discourses and practices, together with the recommendations of the psychologists. This should be taken up with the psychological services to make cultural adjustments to their parenting recommendations. Various studies have shown that incorporating different parenting models yields better results for indigenous women who wish to achieve parenting without violence (Dudgeon et al., 2014; Preston, Cottrell, Pelletier, \& Pearce, 2012; Hinton \& Nagel, 2012).
The results presented are not generalizable to women of all ethnic groups, since the sample does not represent the ethnic diversity of the city. They only allow one to posit that the insertion of women in empowerment processes can help them discourage gender-based violence in their communities and raise their children without the violence they experienced. Although data exist from other parts of the world to support this statement (Lopez-Carmen et al., 2019; Tsey et al., 2010; Kermode et al., 2007; Kar, Pascual, \& Chickering, 1999), further evaluations must be undertaken to demonstrate the effectiveness of empowerment in improving the health of indigenous women (Lindacher et al., 2018; Cyril, Smith, \& Renzaho, 2016).

\section{Funding}

This study was funded by the Secretaria de Educación, Ciencia, Tecnología e Innovación de la Ciudad de México [SECTEI, Secretariat of Science, Technology, and Innovation of Mexico City], formerly SECITI (Agreement number: SECITI / 101/2017).

\section{Conflict of Interest}

The authors declare that they have no conflicts of interest.

\section{REFERENCES}

Almario García, Ó., Das, V., Uribe Alarcón, M. V., Jimeno Santoyo, M., Cavell, S., Meléndez, R., \& Abadía Barrero, C. E. (2008). Veena Das: Sujetos del dolor, agentes de dignidad. Colombia: Universidad Nacional de Colombia/Pontificia Universidad Javeriana/Instituto Pensar.

Berenzon Gorn, S., Galván Reyes, J., Saavedra Solano, N., Bernal Pérez, P., MellorCrummey, L. \& Tiburcio Saínz, M. (2014). Exploración del malestar emocional expresado por mujeres que acuden a centros de atención primaria de la Ciudad de México: Un estudio cualitativo. Salud Mental, 37(4), 313-319. doi: 10.17711/ SM.0185-3325.2014.036

Bonfil Sánchez, P., De Marinis, N., Xotlanihua, B. P. R., \& Martínez Navarro, R. (2017). Violencia de Género Contra Mujeres en Zonas Indigenas en México. México: Secretaría de Gobernación-CONAVIM-CIESAS-CONACyT.

Callaghan, J.E.,Alexander, J. H., Sixsmith, J., \& Fellin, L. C. (2018). Beyond “Witnessing”: Children's experiences of coercive control in domestic violence and abuse. Journal of Interpersonal Violence, 33(10), 1551-1581. doi: 10.1177/0886260515618946

Carrillo-De la Cruz, C. C., Zapata-Martelo, E., Ayala-Carrillo, M. R., \& DíazCervantes, R. (2015). Empoderamiento femenino en la casa de salud de la mujer indígena "manos unidas". Ra Ximhai: Revista Científica de Sociedad, Cultura y Desarrollo Sostenible, 11(2), 47-64.

Cyril, S., Smith, B. J., \& Renzaho, A. M. (2016). Systematic review of empowerment measures in health promotion. Health Promotion International, 31(4), 809-826. doi: 10.1093/heapro/dav059

Das, V. (2008). Lenguaje y cuerpo: transacciones en la construcción del dolor. In Ortega Martínez, F. A. (Ed.). Almario García, Ó., Das, V., Uribe Alarcón, M., Jimeno Santoyo, M., Cavell, S., Meléndez, R. y Abadía Barrero, C. (Authors.). Veena Das: Sujetos del dolor, agentes de dignidad (pp. 343). Bogotá, Colombia: Universidad Nacional de Colombia. Facultad de Ciencias Humanas. Instituto CES.

De Vos, P., Malaise, G., De Ceukelaire, W., Perez, D., Lefèvre, P., \& Van der Stuyft, P. (2009). Participación y empoderamiento en la atención primaria en salud: desde Alma Ata hasta la era de la globalización. Medicina Social, $4(2), 127-134$.

Denzin, N. K., \& Lincoln, Y. S. (2012). El campo de la investigación cualitativa. Barcelona: Editorial Gedisa.

Devries, K., Watts C., Yoshihama, M., Kiss, L., Schraiber, L. B., Deyessa, N. ... Garcia-Moreno, C. (2011). Violence against women is strongly associated with suicide attempts: Evidence from the WHO multi-country study on women's 
health and domestic violence against women. Social Science \& Medicine, 73(1), 79-86. doi: 10.1016/j.socscimed.2011.05.006

Duarte Bastián, A. (2008). Género y procesos organizativos de las mujeres nahuas del sur de Veracruz. In Castro, R., \& Casique, I. (Eds.), Estudios sobre cultura, género y violencia contra las mujeres (pp. 261-290). Cuernavaca, México: CRIM-UNAM.

Dudgeon, P., Walker, R., Scrine, C., Shepherd, C., Calma, T., \& Ring, I. (2014). Effective strategies to strengthen the mental health and wellbeing of Aboriginal and Torres Strait Islander people. Australian Institute of Health and Welfare.

González Montes, S. (2009). Violencia contra las mujeres, derechos y ciudadanía en contextos rurales e indígenas de México. Convergencia, 16(50), 165-185.

Hernández Sánchez, J. E., \& García Falconi, R. (2008). Instrumento para medir el empoderamiento de la mujer. México: Universidad Juárez Autónoma de Tabasco.

Hinton, R., \& Nagel, T. (2012). Evaluation of a culturally adapted training in Indigenous mental health and wellbeing for the alcohol and other drug workforce. ISRN Public Health, 2012, 1-6. doi: 10.5402/2012/380581

Instituto Nacional de Estadística y Geografía [INEGI]. (2012). Encuesta Nacional sobre la Dinámica de las Relaciones en los Hogares (ENDIREH) 2011. Informe operativo. México: INEGI.

Instituto Nacional de Salud Pública. (2008). Encuesta de Salud y Derechos de las Mujeres Indigenas (Primera edición). Retrieved from https:/www.insp.mx/ images/stories/Produccion/pdf/100722_cp7.pdf

Kar, S. B., Pascual, C. A., \& Chickering, K. L. (1999). Empowerment of women for health promotion: a meta-analysis. Social Science \& Medicine, 49(11), 14311460. doi: 10.1016/S0277-9536(99)00200-2

Kermode, M., Herrman, H., Arole, R., White, J., Premkumar, R., \& Patel, V. (2007). Empowerment of women and mental health promotion: a qualitative study in rural Maharashtra, India. BMC Public Health, 7, 225. doi: 10.1186/1471-2458$7-225$

Klein, A., \& Vázquez-Flores, E. (2013). Los roles de género de algunas mujeres indígenas mexicanas desde los procesos migratorios y generacionales. Journal of Behavior, Health \& Social Issues, 5(1), 25-39. doi: 10.5460/jbhsi.v5.1.38611

Lindacher, V., Curbach, J., Warrelmann, B., Brandstetter, S., \& Loss, J. (2018). Evaluation of Empowerment in Health Promotion Interventions: A Systematic Review. Evaluation \& the Health Professions, 41(3), 351-392. doi: $10.1177 / 0163278716688065$

Lopez-Carmen, V., McCalman, J., Benveniste, T., Askew, D., Spurling, G., Langham, E., \& Bainbridge, R. (2019). Working together to improve the mental health of indigenous children: A systematic review. Children and Youth Services Review, 104, 104408. doi: 10.1016/j.childyouth.2019.104408

Morokvasic, M. (2007). Migration, Gender, Empowerment. In Lenz, I., Ullrich, C., \& Fersch, B. (Eds.). Gender Orders Unbound? Globalisation, Restructuring and
Reciprocity (pp. 69-98). Opladen \& Farmington Hills: Verlag Barbara Budrich Publishers. doi: 10.2307/j.ctvdf086s.6

Natera Rey, G., Callejas Pérez, F., Barker, S., Little, T., \& Medina Aguilar, P. (2012). "Pa' qué sirvo yo, mejor me muero": Hacia la construcción de la percepción de sintomatología depresiva en una comunidad indígena. Salud Mental, 35(1), 63-70.

Orton, L., Pennington, A., Nayak, S., Sowden, A., White, M., \& Whitehead, M. (2016). Group-based microfinance for collective empowerment: a systematic review of health impacts. Bulletin of the World Health Organization, 94(9), 694704A. doi: 10.2471/BLT.15.168252

Pérez Villar, M. A., Vázquez García, V., \& Zapata Martelo, E. (2008). Empoderamiento de las mujeres indígenas de Tabasco. El papel de los fondos regionales de la CDI. Cuicuilco, 15(42), 165-179.

Preston, J. P., Cottrell, M., Pelletier, T. R., \& Pearce, J. V. (2012). Aboriginal early childhood education in Canada: Issues of context. Journal of Early Childhood Research, 10(1), 3-18. doi: 10.1177/1476718X11402753

Scheper-Hughes, N. (1992). La muerte sin llanto. Violencia y vida cotidiana en Brasil. Barcelona: Editorial Ariel.

Strauss, A., \& Corbin, J. M. (1990). Basic of qualitative research: Grounded theory procedures and techniques. Londres: Sage Publications, Inc.

Suárez Elizalde, P. (2009). Estudio situacional de las necesidades de atención de las mujeres que enfrentan violencia de género en Amealco y Tolimán, Querétaro. Fondo de fomento para la transversalidad. México: Instituto Nacional de las Mujeres. Retrieved from: http://cedoc.inmujeres.gob.mx/ftpg/ Qro/qro_B_1_1_2009.pdf

Taylor S. J., \& Bogdan, R. (1987). Introducción a los métodos cualitativos: la búsqueda de significados. Barcelona, Paidós.

Tiburcio Sainz, M. A. (2009). Adaptación de un modelo de intervención para familiares de usuarios de alcohol en una comunidad indigena (Tesis de Doctorado). Universidad Nacional Autónoma de México, México. Retrieved from http://132.248.9.195/ptd2009/junio/0645349/Index.html

Tsey, K., Whiteside, M., Haswell-Elkins, M., Bainbridge, R., Cadet-James, Y., \& Wilson, A. (2010). Empowerment and Indigenous Australian health: a synthesis of findings from Family Wellbeing formative research. Health Social Care Community, 18(2), 169-179. doi: 10.1111/j.1365-2524.2009.00885.x

Valdez-Santiago, R., Híjar, M., Rojas Martínez, R., Ávila Burgos, L., \& Arenas Monreal, M. L. (2013). Prevalence and severity of intimate partner violence in women living in eight indigenous regions of Mexico. Social Science \& Medicine, 82, 51-57. doi: 10.1016/j.socscimed.2013.01.016

Vega, L, Rendón, A, Gutiérrez, R, Villatoro, J, Vargas, A, Juárez, A, ...Trejo, S. (2015). Estudio sobre patrones de consumo de sustancias psicoactivas en población indigena residente y originaria de la ciudad de México. México: INPRFM-IAPA 